\title{
TRENDS IN VETERINARY EXPERT OPINIONS ON ANIMALS
}

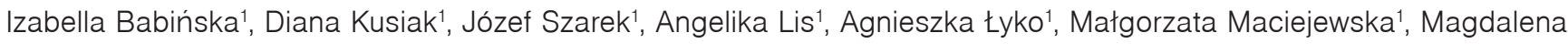 \\ Szweda ${ }^{1}$, Krystian Popławski ${ }^{1}$, Mariusz Z. Felsmann²* \\ ${ }^{1}$ Chair of Pathophysiology, Forensic Veterinary Medicine and Administration, Faculty of Veterinary Medicine, University of Warmia and \\ Mazury in Olsztyn, ul. Oczapowskiego 13, 10-719 Olsztyn, ${ }^{2}$ Centre for Veterinary Sciences, Nicolaus Copernicus University, ul. Gagarina 7 , \\ 86-100 Toruń, Poland \\ ${ }^{*}$ Corresponding author, E-mail: felsmann.mariusz@wp.pl
}

\begin{abstract}
This paper analyses veterinary expert opinions and determines the most common reasons for appointing veterinarians as expert witness in cases related to different animal species. The paper also summarises twenty one years of services provided by the Department of Forensic Veterinary Medicine and Administration, University of Warmia and Mazury in Olsztyn in 1995 - 2015. The analysis was based on 319 expert opinions, of which 172 concerned various animal species and is presented in this work. Criminal judicial bodies were the most common ordering party, followed by civil judicial bodies, natural persons, public administration authorities and insurance companies. To determine the trends in conflicting situations in the expert opinions issued over 21 years, two periods of opinions were distinguished: the first period covering the years 1995 - 2005 (73 expert opinions) and the second one covered 2006 - 2015 (99 expert opinions). The authors demonstrated that in the second period, companion animals (mainly dogs) were far more often the subject of expert opinions than in $1995-2005$ and the cases predominantly referred to animal cruelty issues. The second most common group were production animals (cattle, horses and pigs) followed by wild living animals. The expertopinions concerned the animals themselves butalso animal products, particularly the observance of sanitary and hygiene measures at different manufacturing stages. The diversity of cases and conflicts in which a veterinarian acts as the expert witness is also increasing.
\end{abstract}

Key words: veterinary forensic medicine; expert opinions; animals; conflicts; veterinary practice

\section{Introduction}

In its complexity and diversity, animal breeding and rearing gives rise to numerous conflicting situations which can generate economic losses. This, together with breeders' increasing awareness of legal issues, has led to increasing numbers of conflicts reaching the courts $(1,2)$. Such cases, as they are specific in nature and legal background and need a thorough evaluation of the facts, often require expert opinions based on specialized knowledge $(2,3,4,5)$. For this purpose, judicial bodies appoint veterinarians with theoretical and

Received:29March 2017

Accepted for publication: 19 July 2018 practical expertise of veterinary medicine as an expert witness $(6,7,8,9,10)$.

An expert witness is an auxiliary entity in pre-trial proceedings (investigation or probe) and in the court $(3,9)$. The police, prosecutors and the court itself can question the expert witness, thereby defining the scope of her or his activities $(11,12,13)$. The expert opinion issued by an expert witness equals other forensic evidence and is arbitrarily evaluated by the judicial bodies, whereas an opinion ordered by other entities (a so-called "private opinion") does not serve as evidence in a conflict situation but it is only considered by investigating bodies $(5,10,13,14)$. The role of a veterinarian as an expert witness is to assess the factual circumstances of a given event 
together with specifying its causes and identifying its consequences $(11,15,16,17)$.

The objective of the paper is to analyse the expert opinions issued over twenty years by the Department of Forensic Veterinary Medicine and Administration, University of Warmia and Mazury in Olsztyn and identify the main source of conflicts.

\section{Materials and methods}

The analysis was based on 172 opinions issued in 1995 - 2015 by the Department of Forensic Veterinary Medicine and Administration, University of Warmia and Mazury (UWM) (formerly of the Agricultural and Technical Academy in 1995 - 1999) in Olsztyn, for ordering parties from all over Poland. The analysis included the animal species (except for poultry, due to the specificity of husbandry), the ordering parties, the reasons for conflicts or production failures and decisions/propositions of expert witness. To determine the trends in conflicting situations in the expert opinions issued over 21 years, two periods of opinions were distinguished: the first period covering the years 1995 - 2005 (73 expert opinions) and the second one covered $2006-2015$ (99 expert opinions).

\section{Results and discussion}

Animal species as the subject of conflicts, and entities initiating veterinary expert opinions

It was found that of 172 expert opinions issued in 1995 - 2015 by the Department of Forensic Veterinary Medicine and Administration, UWM, 70 documents referred to dogs, 25 to cattle, 18 to horses, 9 to cats and 10 to pigs. The remaining 40 opinions were related to different animal species, such as wild boars, eagles, rabbits, chinchillas, roe deer, cormorants, turtles and foxes. The animal species and number of expert opinions are presented in Fig. 1.

Judicialbodiesinvolvedincriminalinvestigations (i.e. the courts, police and prosecutors - 70 and civil courts - 57) were the most common ordering parties. A significantly smaller number of expert opinions were issued for private persons (13), different public administration authorities (10), insurance companies (10) and other entities, e.g. hunting clubs, veterinary tribunals and screeners for veterinary professional liabilities (12 expert opinions) (Fig. 2).

\section{Expert opinions on companion animals}

The expert opinions issued for cases in which companion animals were the subject of conflicts were the most numerous group as compared with the opinions on the other animal species. This was particularly true for the second group of expert opinions. Most companion animals were the subject of a conflicting situation in the criminal proceedings. Some of the opinions were associated with necropsies; these included 64 opinions, of which in 58 documents dogs were necropsies and six opinions presented necropsy findings on cats, which constitutes approximately $37 \%$ of all issued expert opinions. During the first analysed period, 21 expert opinions referred to dogs and four to cats while the number of opinions on dogs significantly increased (about 133\%) in the second period.

Almost half of the expert opinions on companion animals focused on animal cruelty issues (37 opinions) and single cases were related to negligence of animal welfare (lack of provision of veterinary care, food deprivation, keeping in poor conditions). In one opinion on poor transport conditions, the expert witness, further to necropsy, discovered that the death of a puppy resulted from PDA (patent ductus arteriosus; a congenital defect) (18). The most common causes of deaths were gunshot wounds (approximately 18\%), poisonings (about 12\%) and drowning/suffocation (approximately 7\%). Most of the cases described were associated with animal abuse. There included mechanical injuries, including hard objects and stab wounds. There was also a case of a dog buried alive and a death due to pylorus obstruction with pieces of bloodmoistened material (such an approach is used to "feed" dogs trained for dog-fighting). In two cases of dogs, necropsy was performed following cadaver exhumation; the causes of death were skull trauma in one case and suffocation in the other case. However, regarding poisonings, in two dogs and three cats the characteristic changes were caused by anticoagulant rodenticide intoxication (17). The origin of those substances was not proven. 
Figure 1: Animal species as the subject of expert opinions and the number of opinions issued by the Department of Forensics Veterinary Medicine and Administration, University of Warmia and Mazury in Olsztyn in 1995 2015

Figure 2: List of the ordering parties and number of expert opinions issued by the Department of Forensics and Veterinary Administration, University of Warmia and Mazury in Olsztyn in 1995 2015
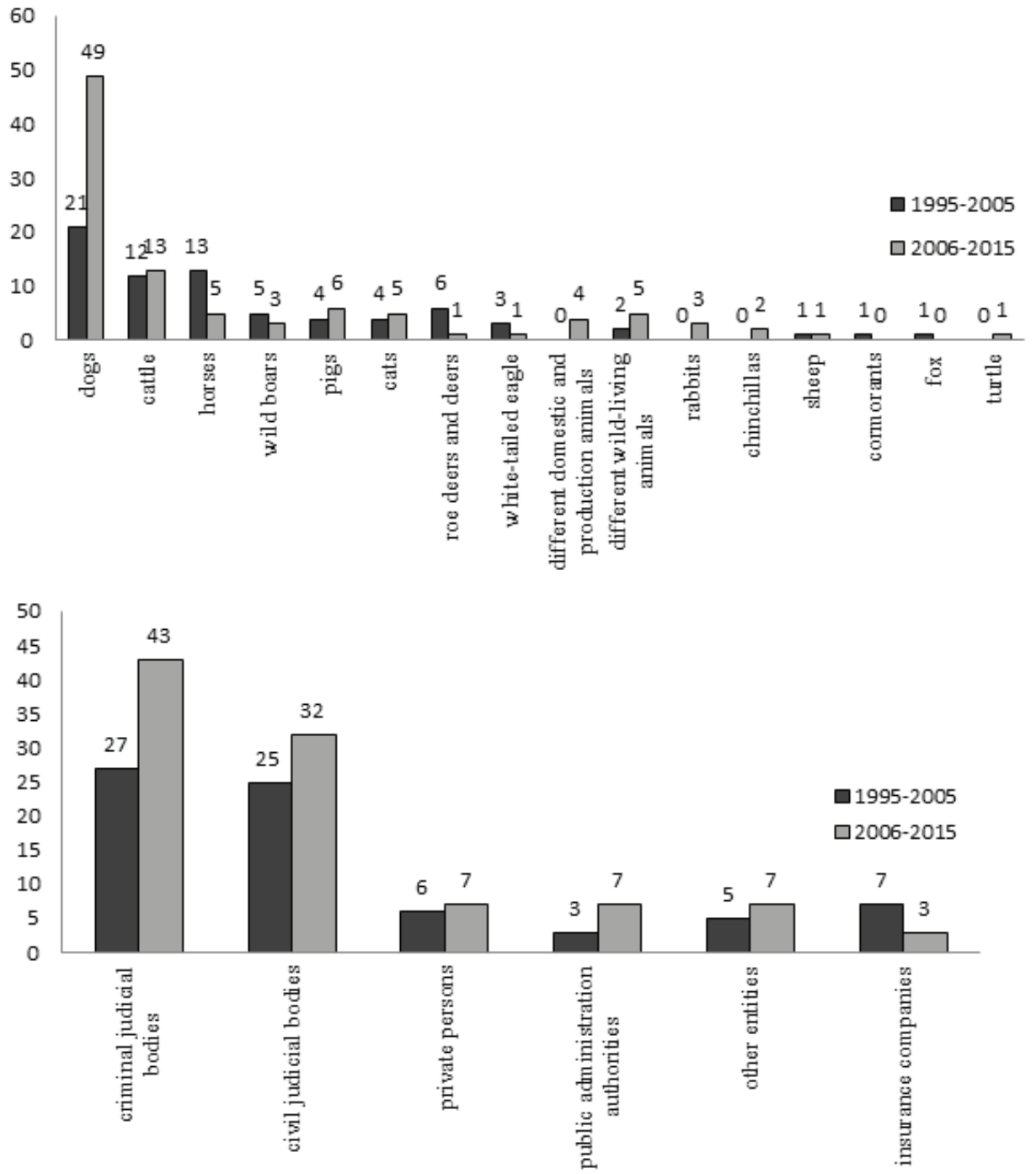

In cases with veterinarians involving being sued, nine expert opinions were issued, with only one included in the first period, concerning a Ragdoll cat suffering from FIP $(5,18)$. In the second decade, eight cases referred to a medical error and the majority of them were linked to negligence during surgical procedures. It was found in two cases that the veterinarian was guilty of post-surgical complications (hernia removal and ovariohysterectomy). One case of internal haemorrhage after orchiectomy in cat was revealed, due to improper diagnosis and treatment. For one Bernese Mountain Dog, elbow dysplasia was not diagnosed and therefore no appropriate treatment was applied. In another case, the veterinary surgeon's error involved excessively tight bandaging on the dog's pelvic limb, after the removal of the skin lesion.
As a result, a soft tissue necrosis occurred, complicated by an anaerobic bacterial infection. The consequence was the amputation of the limb. The patient was a valuable stud dog, which, as a result of the veterinarian's malpractice, could not be used properly.

In three analysed cases, no errors on the part of a veterinarian were discovered. In one of the analysed cases, the death of a bitch after a caesarean section occurred due to toxic shock. In another - a cat died during castration preparations, following anaphylaxis or shock after the administration of the proper aesthetic dose. Another case concerned a dog, in which the causa mortis was pancreatitis and intestinal perforation - but not due to a diagnostic laparotomy carried out by the veterinarian. 
In four cases $(5 \%)$, the expert opinions concerned conflicts associated with the sale transactions of animals (19). In two of them it was found that the purchased animals were not suitable for reproduction purposes due to a urogenital tract disease in a bitch and hip dysplasia in a male dog. Two further cases concerned puppies: in one case, the expert witness demonstrated in a necropsy that gastric torsion, and not a congenital defect, was the cause of death (18). In the second case, it was shown that incorrect prophylaxis resulted in an infectious disease (canine parvovirus infection).

One of the expert opinions was issued in relation to a veterinary technician who performed surgery on an animal in breach of his authorisation. His actions resulted in a prolonged healing time of the surgical site and, consequently, to potentiated suffering of the animal and higher treatment costs. In another case, the expert witness identified a missing dog based on the analysed materials. In one of the issued opinions, the case was initiated at the request of a screener for veterinary professional liability who claimed that a veterinarian had made medical errors during a caesarean section surgery resulting in the death of a bitch. Both the opinion and pre-trial proceedings proved that labour assistance was performed in the correct manner $(19,20)$.

\section{Expert opinions on production animals}

Of the analysed expert opinions, 25 documents concerned cattle $(14.5 \%)$, mainly dairy cows (19), calves (3) and heifers (3). The rate of conflicts related to this species was similar over two periods.

It was found that 11 expert opinions were requested by criminal judicial bodies. Four of these opinions concerned animal cruelty (lack of veterinary care and of proper nursing, starvation, excessive animal compaction), two were associated with identifying the cause of death and one expert opinion referred to an epidemiological risk created by bovine enzootic pneumonia. Another opinion was aimed at determining the losses caused by a driver involved in a car accident involving a cow. In one of the opinions, the veterinarian was found to have acted correctly in a case involving the diagnostic slaughtering of five cows. Another case involving criminal proceedings concerned the use of a falsified health certificate that was issued in an erroneous manner by a veterinarian.
As a result, a claimant purchased cattle infected with rhinotracheitis infections. The last expert opinion in criminal proceedings referred to a cow which was in labour when transported to a slaughterhouse together with a calf with a broken limb; the animals were exposed to stress and suffering (21).

Fourteen expert opinions were requested by civil judicial bodies. In seven cases, the ordering parties were insurance companies and in four of such situations, a medical error by a veterinarian was proven and, in one case, reduced utility value of dairy cows was determined. Two expert opinions concerned the suitability of dead cow meat for consumption (the cows suffered from fatal electric shock). One case was aimed at determining the cause of a high somatic cell count in milk and another case involved determining whether it had been possible to prevent the death of a cow during labour. Issues related to veterinary malpractice concerned both complications due to surgical procedures (causing heavy haemorrhage after the uterine artery cut, during caesarean surgery; incorrect birth assistance) and non-compliance with the asepsis rules of vaccination.

An analysis of one case concerned damages to an owner who did not meet his contractual duties, resulting in the euthanasia of an animal. In one of the expert opinions, the expert witnesses were requested to determine whether incorrect installation of silos resulted in diseases and losses of animals. An analysis of factual circumstances demonstrated that the losses were the result of intoxication caused by improperly stored feed. One opinion was requested by a pharmaceutical company. The case concerned determining the occurrence of post-vaccine adverse effects such as local reactions and general malaise of animals. The expert witness found that the poor health condition of cattle was due to Trueperella pyogenes bacterium. The infection probably resulted from bacteria entering the body at the vaccine injection site $(20,22)$. In one of the cases it was shown that an incorrectly formulated feed ration which triggered ketosis was complicated by a BVD/ MD virus infection and Clostridium perfringens enteric toxin (22). In other cases, analyses were conducted to determine the cause of reduced milk production and fertility as well as deaths in cows due to incorrectly balanced feed rations.

Ten expert opinions concerned pigs $(5.8 \%$ of the analysed cases), of which six cases were requested 
by civil judicial bodies, two by criminal judicial bodies and the other two by private persons. Seven of sale transactions and one referred to settling the health status of weaners brought onto a farm by a petitioner. In one of the expert opinions, the cause of death and reduced growth rates in pigs was determined (salmonellosis) (22). Another case concerned determining the losses incurred by a producer who caused a fire in a swine facility.

Two expert opinions concerned sheep (1.2\%). In one of them, the issue was to determine the cause of losses in sheep production (pulmonary adenomatosis was found to be the cause). The other case referred to the death of sheep resulting from spinal cord insult and multiple bite wounds.

A comparison of two periods (1995 - 2005 and 2006 - 2015) demonstrates that the proportion of expert opinions on production animals was at a comparable level.

\section{Expert opinions on horses}

The analysis showed that 18 (10.5\%) expert opinions concerned horses. Of them, eight opinions referred to poor husbandry and management with negligence, beating and work overload. In two criminal proceedings, it was proven that horses (including Konik horses) were kept under inadequate husbandry conditions in autumn and winter seasons. They were incorrectly fed and deprived of proper veterinary care (20). Seven expert opinions questioned the actions of a veterinarian. In one case, a case of death was analysed (a person kicked by a Hucul horse). In three opinions, fraud was revealed in sale and purchase transactions, i.e. selling horses with physical defects preventing the stated purpose of the animals $(4,19)$. Over 21 years, the proportion of cases involving horses has changed significantly: in the second time period (2006 - 2015), the number of such expert opinions decreased by over $60 \%$.

\section{Other expert opinions}

Other expert opinions constitute approximately $20 \%$ of cases (34 opinions). Among them, over half concern wild-living animals such as roe deer, deer, wild boars, eagles or foxes. Most of them were related to determining the cause of death, of which shotgun wounds were the most common (23). In one expert opinion on a white-tailed eagle, the necropsy revealed cardiorespiratory failure due to mechanical trauma as the cause of death. The expert witnesses were equally often requested to identify an animal species from which meat and illegally owned hunting trophies (such as skin or antlers) were obtained. One opinion was requested by a natural person and concerned a comparison of submitted canine hair with a hair coat found on the fence of premises. It was identified as fox hair. In another case, the role of expert witness, as requested by an insurance company, was to determine whether damage to a car was caused by a traffic accident involving a wild boar (9).

Veterinarians also act as expert witness in cases involving people or their property. Three such opinions concerned damage for traffic accidents involving a wild boar, a cow and a dog. In one case of an expert opinion requested by a poultry slaughter house, the role of the expert witness was to determine whether the retina of an employee could have been damaged by turkey bile. Within the investigated time period, two cases concerning the deaths of humans were analysed. In the first case, the expert witness was requested to determine whether the injuries of a victim were inflicted by a horse kick (Hucul horse). In the second case, the court questioned the possibility of isolating human DNA from the faeces of dogs suspected of the fatal biting of a person.

Among cases involving rabbits, one expert opinion was requested by a pharmaceutical company on the adverse effects of a vaccine. In the second case, the expert witness assessed the correctness of a necropsy procedure performed by a veterinarian. In another case, the expert witness ruled out any impact of poor quality feed on animal deaths (in fact, infectious rhinitis was the aetiology).

In ten cases, products of animal origin were questioned. One expert opinion requested by an investigation body concerned the species origin and quality of a meat bath. The expert witness found significant discrepancies in storage conditions (hygiene aspects) and the quality of the tested material. In three expert opinions (including two complementary opinions), the expert witness was asked to estimate the value of meat after a road traffic accident. Due to the disruption of the cold chain, prolonged transport time and significant contamination, the meat was labelled as unsuitable for consumption or processing. Two expert opinions (major and supplementary) 
concerned the infection of 225 persons with trichinosis. In that particular case, the expert witness did not find any negligence on the part of the employees of a slaughterhouse from where the meat had originated. Another two opinions were linked to the evaluation of an animal-derived product: pork fat contaminated with bristles and skin fragments. In two other cases brought against a district veterinary office, the expert witness found that the inspection frequencies in the abattoirs were insufficient and the records were erroneous.

Exotic animals were a rare subject of veterinary expert opinions. Over 21 years, only one opinion was issued and it regarded the species identification of a turtle. The expert witness stated that submitted photos represented a red-eared slider, a species that presents a risk to the native European pond turtle if it adapts to local climatic conditions.

The expert opinions issued on different animal species most often concerned animal cruelty, welfare negligence and poor husbandry conditions for production and companion animals. Within the selected time period, four such opinions were issued, including one brought against an animal shelter $(2,9,16,18)$.

\section{Discussion}

It was shown that the expert opinions were most often issued on companion animals (45.9\%), mainly on dogs (40.7\%), although in $1995-2005$ $34.2 \%$ of the expert opinions concerned companion animals and this number increased to $54.5 \%$ in the years 2006 - 2015. This is partly due to the increase in the number of companion animals in Poland. During this period, the population of these animals increased by approximately $2 \%$ per year (24). In addition the data indicate that conflicts based on animal treatment are increasing in Poland. An increasing tendency, as a reflexion of the presented facts, can be observed in issuing expert opinions as well. An analysis of the literature also indicates that this is a fairly common trend all around the world $(9,12,16)$. The literature also indicates that awareness in providing animals with adequate welfare and, consequently, the need to respond to their harm is increasing $(1,16$, $25,26)$. It can be concluded that the increasing amount of expert veterinary opinions being issued are due to these, and not from a rise in human cruelty towards accompanying animals (25). This thesis is also supported by the increase in the number of shelters and accompanying animals staying in them $(24,27)$.

Production animals (such as cattle, horses and pigs) were the second-most common group of animals involved in these reports (32\%). The cases of wild-living animals constituted 16.3\% and mainly referred to poaching, illegal ownership of hunting trophies or identification of carcasses or meat from game animals. The other $5.8 \%$ of all expert opinions issued by the Department of Forensic Veterinary Medicine and Administration, University of Warmia and Mazury in Olsztyn encompassed varied aspects, such as animal origin products and compensation for traffic accidents involving animals.

An analysis of conflict etiology regarding companion animals shows that almost half of the opinions concerned animal cruelty (31 opinions). This fact indicates a relatively steady elimination of this phenomenon. The authors quoted emphasize the growth of common empathy for the suffering animals $(1,25)$. On the other hand, the recorded rise in the number of opinions related to the gunshot injuries to animals can be explained by changes in legal regulations facilitating weapon possession (28). The widespread availability of firearms results in both intentional and accidental injuries to animals $(29,30,31)$.

A growing trend in issuing opinions concerning veterinarian malpractice can also be observed $(9$, $32,33)$. In this paper, $2 / 3$ of such cases revealed the veterinary surgeon's culpability. Relatively often, these cases involved insurance companies taking legal action.

The data indicates that the knowledge, expertise and experience of veterinarians serve both judicial bodies and different administration authorities, institutions and private persons and the diversity of cases and conflicts in which a veterinarian acts as an expert witness is also increasing $(1,2,5,7$, $12,15,16,25,26)$.

\section{Recapitulation}

The analysis of the expert opinions issued by the Department of Forensic Veterinary Medicine and Administration, University of Warmia and Mazury in Olsztyn in 1995 - 2015 demonstrated 
that most of the opinions were requested by criminal judicial bodies (40.7\%) followed by civil judicial bodies $(33.1 \%)$, natural persons $(7.6 \%)$ and public administration authorities and insurance companies (5.8\% each).

A comparison of the expert witness opinions issued in two investigated decades 1995 - 2015 demonstrated that the total number of opinions on different animal species was higher (by approximately $26 \%$ ) in the second decade than in the first one.

The expert opinions that were issued concerned, apart from an assessment of prophylaxis and treatment choices, evaluation of husbandry conditions, animal welfare, feeding and animal identification as well as the biological materials of animal origin, entering into sale transactions and observing legal veterinary regulations.

\section{References}

1. Lockwood R. Animal cruelty and human violence: the veterinarian's role in making the connection: the American experience. Can Vet J 2000; 41: 876-8.

2. Ottinger T, Gavier-Widen D, Segerstad $\mathrm{CH}$, et al. Development of veterinary forensic pathology from crime scene to court. J Comp Pathol 2012; 146: 61.

3. Szarek J, Przeździecka D. Lekarz weterynarii jako biegły sadowy. Mag Wet 2000; 9: 50-1.

4. Lipińska J, Szarek J, Przeździecka D. Wady fizyczne koni w świetle polskich aktów prawnych $z$ początku, przełomu i końca XX wieku. Med Wet 2004; 60: 570-2.

5. Listos P, Gryzińska M, Kowalczyk M. Badanie pośmiertne $\mathrm{w}$ aspekcie weterynarii sadowej. Życie Wet 2016; 91: 106-9.

6. Babińska I, Szarek J, Wojtacka J. Aspekty konfliktogenne w chowie i hodowli zwierzat w opiniach weterynaryjnych. Med Wet 2006; 62: 113943.

7. Forbes N. An exacting science: the veterinary surgeon as expert witness. In Pract 2004; 26: 503-6.

8. Góra-Błaszczykowska A. Opinia biegłego w postępowaniu cywilnym. Eduk Prawnicza, 2005; 67: 3-8.

9. Ottinger T, Rasmusson B, Segerstad CHA, et al. Forensic veterinary pathology, today's situation and perspectives. Vet Rec 2014; 175: 459.
10. Regulation of the Minister of Justice dated 24 January 2005 on court experts. Dz U 2005; (15): item 133. (Dziennik Ustaw)

11. Szarek J. Lekarz weterynarii jako biegły. Wydanie V poprawione i uzupełnione. Olsztyn, Poland: Wydawnictwo UWM, 2005: 12-21, 66-70.

12. Listos P, Gryzinska M, Kowalczyk M. Analysis of cases of forensic veterinary opinions produced in a research and teaching unit. $\mathrm{J}$ Forensic Leg Med 2015; 36: 84-9.

13. Turek J. Biegły sadowy i jego czynności. MoP 2007; 24: 1359-64.

14. Dzierżanowska J, Studzińska J. Kryteria oceny dowodu $z$ opinii biegłego w orzecznictwie sądów powszechnych i Sądu Najwyższego. Rocz Nauk Praw 2015; 25: 21-47.

15. Harris JM. The role of the practicing veterinarian as an expert witness. Semin Avian Exot Pet Med 1998; 7: 176-81.

16. McEven BJ. Trends in domestic animal medico-legal pathology cases submitted to a veterinary diagnostic laboratory 1998-2010. J Forensic Sci 2012; 57: 1231-3.

17. Newbery S, Munro R. Forensic veterinary medicine: 1 . Investigation involving live animals. In Pract 2011; 33: 220-7.

18. McGavin MD, Zachary JF. Pathologic basis of veterinary disease. $5^{\text {th }}$ ed. St. Louis : Mosby Elsevier, 2007.

19. Babińska I, Szarek J, Naumowicz K, et al. Wady fizyczne i prawne zwierząt w świetle aktów normatywnych. Med Wet 2018; 74: 276-9.

20. Maciejewska M, Lis A, Łyko A, Kusiak D. Analiza opinii i ekspertyz z zakresu medycyny weterynaryjnej. In: XLIV Międzynarodowe Seminarium Kół Naukowych KNMAiU KRESKA. Olsztynie, 2015: 2134-9.

21. Act dated 21 August 1997 on animal protection. Dz U 1997; (111): item 724.

22. Quinn PJ. Veterinary microbiology and microbial disease. Oxford : Wiley-Blackwell, 2011.

23. Felsmann MZ, Szarek J, Felsmann M, et al. Factors affecting temporary cavity generation during gunshot wound formation in animals: new aspects in the light of flow mechanic: a review. Vet Med Czech 2012; 57: 569-74.

24. Czworonożni przyjaciele naszych domostw. Warszawa : Taylor Nelson Sofres Ośrodek Badania Opinii Publicznej, 1999.

25. Gerdin JA, McDonough SP. Forensic pathology of companion animal abuse and neglect. Vet Pathol 2013; 50: 994-1006. 
26. Benetato MA, Reisman R, McCobb E. The veterinarian's role in animal cruelty cases. J Am Vet Med Assoc 2011; 238: 31-4.

27. Jurkowska O. Działania mające na celu zmniejszenie populacji bezdomnych psów. Warszawa : Krajowa Szkoła Administracji Publicznej, 2011: 5-7.

28. Act dated 21 May 1999 on weapons and ammunition. Dz U 1999; (53): item 549.

29. Sansom J, Labruyere J. Penetrating ocular gunshot injury in a Labrador Retriever. Vet Ophthalmol 2012; 15: 115-22.

30. Listos P, Komsta R, Łopuszyński W, et al. Radiological and forensic veterinary analysis of gunshot cases in eastern Poland. Med Wet 2016; 72: 453-7.

31. Pavletic MM, Trout NJ. Bullet, bite, and burn wounds in dogs and cats. Vet Clin North Am Small Anim Pract 2006; 36: 873-93.

32. Brodbelt D. Feline anesthetic deaths in veterinary practice. Top Companion Anim Med 2010; 25: 189-94.

33. Mellanby R, Herrtage M. Survey of mistakes made by recent veterinary graduates. Vet Rec 2004; 155: 761-5.

\section{TRENDI STROKOVNIH VETERINARSKIH MNENJ O ŽIVALIH}

\section{Babińska, D. Kusiak, J. Szarek, A. Lis, A. Łyko, M. Maciejewska, M. Szweda, K. Popławski, M. Z. Felsmann}

Povzetek: Prispevek presoja veterinarska strokovna mnenja in določa najpogostejše razloge za imenovanje veterinarjev kot strokovnjakov v primerih, povezanih z različnimi živalskimi vrstami. V prispevkuje povzetih 21 let službe Oddelka zaforenzično veterinarsko medicino in administracijo na Univerzi Warmia in Mazury v Olsztynu, in sicer od 1995 do 2015. Analiza je temeljila na 319 strokovnih mnenjih, od katerih jih je 172 obravnavalo različne živalske vrste, ki so predstavljene v tej študiji. Najpogostejši naročnik so bili kriminalni pravosodni organi, nato pa so sledila civilna pravosodna telesa, fizične osebe, organi javne uprave in zavarovalnice. Za določitev trendov v konfliktnih situacijah v strokovnih mnenjih, izdanih v zadnjih 21 letih, je bila raziskava razdeljena na dve ločeni obdobji: prvo obdobje od leta 1995 do leta 2005 (73 strokovnih mnenj) in drugo obdobje, ki zajema čas od leta 2006 do leta 2015 (99 mnenj strokovnjakov). Avtorji so pokazali, da so v drugem obdobju ljubiteljske vrste živali (predvsem psi) veliko bolj pogosto predmet strokovnih mnenj kot v zgodnejšem obdobju (1995 - 2005), pri čemer so se mnenja v največ primerih nanašale na vprašanja krutega ravnanja z živalmi. Druga najpogostejša skupina so bile proizvodne živali (govedo, konji in prašiči), tem pa so sledile divje živali. Strokovna mnenja so se nanašala na same živali, pa tudi na živalske proizvode, zlasti na upoštevanje sanitarnih in higienskih ukrepov na različnih stopnjah proizvodnje. Raznolikost primerov in konfliktov, v katerih veterinar deluje kotizvedenec se je prav tako povečalo.

Ključne besede: veterinarska forenzična medicina; strokovna mnenja; živali; konflikti; veterinarska praksa 